\title{
Sequence analysis for detection of drug resistance in Mycobacterium tuberculosis complex isolates from the Central Region of Cameroon
}

Emmanuel Mouafo Tekwu ${ }^{1,5,6 \dagger}$, Larissa Kamgue Sidze ${ }^{1,5,6+}$, Jean-Paul Assam Assam 1,6, Jean-Claude Tedom, Serges Tchatchouang ${ }^{1,6}$, Gaëlle Guiewi Makafe ${ }^{1,6}$, Anne-Laure Tchokote Wetewale ${ }^{1,6}$, Christopher Kuaban², Sara Eyangoh ${ }^{3}$, Francine Ntoumi ${ }^{4,5,6}$, Véronique N Penlap Beng ${ }^{1,6^{*}}$ and Matthias Frank ${ }^{5,6,7^{*}}$

\begin{abstract}
Background: The potential of genetic testing to rapidly diagnose drug resistance has lead to the development of new diagnostic assays. However, prior to implementation in a given setting, the association of specific mutations with specific drug resistance phenotypes should be evaluated. The purpose of this study was to evaluate molecular markers in predicting drug resistance in the Central Region of Cameroon.

Results: From April 2010 and March 2011, 725 smear positive pulmonary tuberculosis patients were enrolled and all positive cultures were tested for drug susceptibility. A total of 63 drug resistant and 100 drug sensitive Mycobacterium tuberculosis complex clinical isolates were screened for genetic mutations in $k a t G$, inhA, ahpC, rpoB, rpsL, rrs, gidB and embCAB loci using DNA sequencing. Of the 44 isoniazid resistant $\left(I_{N} H^{R}\right)$ isolates (24 high level, $1 \mathrm{\mu g} / \mathrm{ml}$ and 20 low level, $0.2 \mathrm{\mu g} / \mathrm{ml}), 73 \%$ (32/44) carried the katG315 and/or the $-15 \mathrm{inh} A$ promoter mutations. Of the 24 high level INH, $17(70.8 \%)$ harbored katG315 mutation, 1 a point mutation $(-15 \mathrm{C} \rightarrow \mathrm{T})$ in the inhA promoter and 6 were (25.0\%) wild types. Thus, for $\mathbb{N N H}^{R}$ high level detection, katG315 mutation had a specificity and a sensitivity of $100 \%$ and $70.8 \%$ respectively. Of the 20 low level INH ${ }^{R}, 10(50.0 \%)$ had a $-15 \mathrm{C} \rightarrow$ T mutation in the inhA promoter region, and $1(2.2 \%)$ a $-32 \mathrm{G} \rightarrow \mathrm{A}$ mutation in the $\mathrm{ahpC}$ promoter region. All of the 7 rifampicin resistant $\left(\mathrm{RIF}^{\mathrm{R}}\right)$ isolates carried mutations in the rpoB gene (at codons Ser531Leu (71.4\%), His526Asp (14.3\%), and Asp516Val (14.3\%)). Of the 27 streptomycin resistant $\left(S^{R}\right)^{R}$ isolates, 7 carried mutations at the rpsL and the gidB genes. 1 of the 2 ethambutol resistant $\left(E M B^{R}\right)$ isolates displayed a mutation in embB gene.

Conclusion: This study provided the first molecular investigation assessing the correlation of phenotypic to genotypic characteristics on MTB isolates from the Central Region of Cameroon using DNA sequencing. Mutations on rpoB, katG315 and -15 point mutations in inhA promoter loci could be used as markers for RIF and INH -resistance detection respectively.
\end{abstract}

Keywords: Phenotype, Mutation, Drug resistance, Mycobacterium tuberculosis, Cameroon

\footnotetext{
*Correspondence: v.penlap@yahoo.fr; Matthias.Frank@uni-tuebingen.de

${ }^{\dagger}$ Equal contributors

'Laboratory for Tuberculosis Research (LTR), Biotechnology Centre (BTC)-Nkolbison, University of Yaoundé I, Yaoundé, Cameroon

${ }^{5}$ Institute for Tropical Medicine, University of Tübingen, Tübingen, Germany

Full list of author information is available at the end of the article
} 


\section{Background}

Despite the availability of an effective treatment for decades, tuberculosis (TB) continues to cause great mortality and suffering, especially in poor and less-developed countries. Its association with the HIV/AIDS pandemic forms a lethal combination. In addition, multidrug resistant (MDR) TB and the recently-described extensively drug resistant (XDR) TB severely complicate the management and control of the disease worldwide [1,2]. Almost 8.8 million new cases of TB were reported in 2010, and 1.4 million deaths were attributed to the disease. Asia and Sub-Saharan Africa accounted for $85 \%$ of new cases of TB worldwide [3]. Of the 8.8 million incident cases in 2010, 1.1 million (13\%) were among people living with HIV.

Tuberculosis remains a common disease in Cameroon, with an estimated of 25000 cases annually [4]. Like in other poor resources countries, therapeutic decisions are most often made by algorithms according to $\mathrm{WHO}$ guidelines. Inadequate or improper prescription of drugs, poor patient compliance and supervision of therapy may lead to the emergence of drug resistant strains [5]. Drug resistance in tuberculosis (TB) is a matter of great concern for TB control programs since these strains could spread in the community, stressing the need for early detection of drug resistance and subsequently initiation of adjusted therapy. Conventional diagnosis of drug-resistance in MTB strains relies heavily upon mycobacterial culture and drug susceptibility testing in liquid or solid media. Usually, results are only obtained after weeks to months of incubation and many developing countries lack the resources to establish the stringent laboratory conditions needed for these growth-based methods. From a clinical perspective, the existing growth-based diagnostics are too slow as patients undergoing treatment with drugs to which they are resistant, remain contagious, and those with XDRTB and HIV often die before they are even diagnosed [6]. Major advances in molecular biology and the availability of new information generated after deciphering the complete genome sequence of M. tuberculosis [7], have led to the development of new tools for rapid detection of drug resistance $[8,9]$. Molecular methods are based on assigning the presence or absence of certain mutations in specific positions or genetic locations which are known to be associated with resistance [10]. About 95\% of rifampicin (RIF) -resistant strains have mutations in the 81-bp core region of the $r p o B$ gene encoding the $\beta$-subunit of the RNA polymerase, named RIF-Resistance Determining Region (RRDR) [11]. In contrast to RIF, the situation for isoniazid (INH) is much more complex. Resistance mutations have been reported in at least 4 different genes including katG, inhA, ahpC and oxyR [10]. Meanwhile, resistance against streptomycin (SM) has been reported to be associated with mutations in $\mathrm{rrs}$ gene, which codes for $16 \mathrm{~S}$ ribosomal RNA, and rpsL coding for the ribosomal protein S12 [12] and these mutations are found in a limited proportion of clinically isolated SM-resistant M. tuberculosis strains. Recently, Okamoto et al. [13] found that mutations within the gidB gene which encodes a conserved 7-methylguanosine $\left(\mathrm{m}^{7} \mathrm{G}\right)$ methyltransferase specific for the 16S rRNA, is associated with low-level SM-resistance and are an important cause of resistance found in 33\% of resistant M. tuberculosis isolates. Resistance to ethambutol (EMB) is primarily mediated by mutations in the $e m b B$ gene, coding for an arabinosyltransferase participating in mycobacterial cell wall synthesis, with codon 306 being most frequently affected [14]. Furthermore, mutations in the $e m b A[15,16]$ and upstream of $e m b C[16,17]$ are also involved in EMB -resistance.

Since the frequency and type of gene mutation varies greatly among different geographic regions in the world [18], it is important to evaluate the type and distribution of resistance associated mutations as a prerequisite for a large-scale implementation of genotypic approaches aimed at rapidly detecting resistance. However, up to now data assessing sensitivity and specificity of specific mutations for the detection of drug resistance phenotypes in our settings is still unavailable. Therefore CANTAM (Central Africa Network for Tuberculosis, HIV/AIDS and Malaria) an EDCTP (European and Developing Clinical Trials Partnership) funded network [19], with the goal to establish a cohort and prepare new sites for conducting future clinical trials of new TB drugs and vaccines in Central Africa countries, carried out a population based study, involving MTBC strains from Central region of Cameroon, to determine the genetic basis of first line drug resistance.

\section{Methods \\ Mycobacterial isolates}

During this baseline study carried out between April 2010 and March 2011, 725 smear positive pulmonary tuberculosis patients were enrolled at Jamot Hospital and Mbalmayo District Hospital. All positive cultures were tested for drug susceptibility to INH $(0.2 \mu \mathrm{g} / \mathrm{ml}$ and $1 \mu \mathrm{g} / \mathrm{ml})$, RIF (40 $\mu \mathrm{g} / \mathrm{ml})$, EMB $(2 \mu \mathrm{g} / \mathrm{ml})$, SM $(4 \mu \mathrm{g} / \mathrm{ml})$, OFX $(2 \mu \mathrm{g} / \mathrm{ml})$ and KAN $(20 \mu \mathrm{g} / \mathrm{ml})$ by the indirect proportion method on Lowenstein Jensen medium [20]. Phenotypically, 44 isolates were $\mathrm{INH}^{\mathrm{R}}$ (24 high level and 20 low level), 27 isolates were $\mathrm{SM}^{\mathrm{R}}, 7$ isolates were $\operatorname{RIF}^{\mathrm{R}}$ and 2 isolates were $\mathrm{EMB}^{\mathrm{R}}$. The 63 resistant isolates to INH, RIF, SM and EMB or MDR were screened for genetic mutations. In addition, M. tuberculosis strain H37Rv (susceptible) and 100 fully susceptible clinical isolates from the panel of susceptible strains collected during the study period were included to serve as controls. The study was approved by the Cameroon National Ethic Committee 
and the Cameroonian Ministry of Public Health. Written informed consent was obtained from all study subjects.

\section{DNA extraction}

Briefly, a loop-full of mycobacterial colonies was suspended in $400 \mu \mathrm{l}$ of $10 \mathrm{mM}$ Tris- $\mathrm{HCl}, 1 \mathrm{mM}$ EDTA ( $\mathrm{pH}$ 7.0) buffer and inactivated at $90^{\circ} \mathrm{C}$ for $30 \mathrm{~min}$. The suspension was then centrifuged at 12,000 $\mathrm{g}$ for $1 \mathrm{~min}$ and the supernatant, containing nucleic acids, was harvested and transferred into a new eppendorf tube. Crude DNA extracts were stored at $-20^{\circ} \mathrm{C}$ and then shipped to Germany for molecular analysis according to International Air Transport Association guidelines.

\section{PCR amplification of target genes}

The DNA extract was used as a template for PCR with the primers listed in Table 1. Each final PCR volume of $20 \mu \mathrm{l}$ contained 10× PCR buffer (Qiagen, Germany), 5\% DMSO, $20 \mathrm{pmol}$ of forward and $20 \mathrm{pmol}$ of reverse primers, $11.9 \mu \mathrm{l}$ of distilled water, $0.5 \mu \mathrm{l} \mathrm{MgCl}_{2} 25 \mathrm{mM}$ (Qiagen, Germany), dNTPs at a final concentration of $500 \mu \mathrm{M}, 0.2 \mu \mathrm{l}$ of Taq polymerase $5 \mathrm{U} / \mu \mathrm{L}$ (Qiagen,
Germany), and $2 \mu \mathrm{l}$ of crude DNA extract ( $\approx 50 \mathrm{ng})$. The cycling program included a cycle of an initial denaturation step at $94^{\circ} \mathrm{C}$ for $5 \mathrm{~min}$, followed by 35 cycles of denaturation at $94^{\circ} \mathrm{C}$ for $1 \mathrm{~min}$, annealing at the temperature and time indicated in Table 1 , and elongation at $72^{\circ} \mathrm{C}$ for $1 \mathrm{~min}$. The final elongation step was set at $72^{\circ} \mathrm{C}$ for $10 \mathrm{~min}$ for one cycle. The PCR products were examined by gel electrophoresis and purified by use of a Nucleospin Extract II kit (Macherey Nagel, Germany) according to the manufacturer instructions.

\section{Sequencing}

Purified PCR products were sequenced with the same primers using the ABI's Big dye terminator kit (Applied Biosystems, USA) according to the manufacturer's instructions. At each locus, both forward and reverse primers at each locus were included in order to maximize the coverage of the amplified gene fragment, and the reproducibility of the results. Sequencing reactions include $1 \mu \mathrm{l}$ big dye, $2 \mu \mathrm{l}$ sequencing buffer, $0.5 \mu \mathrm{l}$ of each $2.5 \mu \mathrm{M}$ primer, a volume of PCR template corresponding approximately to 2-3 ng of DNA, and sufficient distilled water for

Table 1 Primers used in the study

\begin{tabular}{|c|c|c|c|c|c|}
\hline Loci & Primers & Sequences & Annealing $\mathrm{T}^{\circ}$ (time) & Expected size & Reference \\
\hline \multirow[t]{2}{*}{ katG } & $\mathrm{F}$ & 5'-GAAACAGCGGCGCTGATCGT-3' & $66^{\circ} \mathrm{C}(1 \mathrm{~min})$ & $210 \mathrm{bp}$ & [21] \\
\hline & $\mathrm{R}$ & 5'- GTTGTCCCATTTCGTCGGGG- 3' & & & \\
\hline \multirow[t]{2}{*}{ fabGl-inhA } & $\mathrm{F}$ & 5'-CCTCGCTGCCCAGAAAGGGA-3' & $64^{\circ} \mathrm{C}(1 \mathrm{~min})$ & $248 \mathrm{bp}$ & [21] \\
\hline & $\mathrm{R}$ & 5'-ATCCCCCGGTTTCCTCCGGT-3' & & & \\
\hline \multirow[t]{2}{*}{$\operatorname{inh} A(O R F)$} & $\mathrm{F}$ & 5'- GAACTCGACGTGCAAAAC - 3' & $55^{\circ} \mathrm{C}(45 \mathrm{sec})$ & $207 \mathrm{pb}$ & [18] \\
\hline & $\mathrm{R}$ & $5^{\prime}-$ CATCGAAGCATACGAATA - 3' & & & \\
\hline \multirow[t]{2}{*}{$\operatorname{ahpC}$} & $\mathrm{F}$ & 5'-ACCACTGCTTTGCCGCCACC-3' & $65^{\circ} \mathrm{C}(1 \mathrm{~min})$ & $237 \mathrm{bp}$ & [21] \\
\hline & $\mathrm{R}$ & 5'-CCGATGAGAGCGGTGAGCTG-3' & & & \\
\hline \multirow[t]{2}{*}{ rpoB } & $\mathrm{F}$ & 5'-TCGCCGCGATCAAGGAGT-3' & $62^{\circ} \mathrm{C}(30 \mathrm{sec})$ & $158 \mathrm{bp}$ & [21] \\
\hline & $\mathrm{R}$ & 5'-GTGCACGTCGCGGACCTCCA-3' & & & \\
\hline \multirow[t]{2}{*}{$\operatorname{rrs} 530$} & $\mathrm{~F}$ & 5'-GATGACGGCCTTCGGGTTGT-3' & $62^{\circ} \mathrm{C}(1 \mathrm{~min})$ & $238 \mathrm{bp}$ & [12] \\
\hline & $\mathrm{R}$ & $5^{\prime}-$ TCTAGTCTGCCCGTATCGCC -3' & & & \\
\hline \multirow[t]{2}{*}{$\operatorname{rrs} 912$} & $\mathrm{~F}$ & $5^{\prime}$ - GTAGTCCACGCCGTAAACGG -3' & $62^{\circ} \mathrm{C}(1 \mathrm{~min})$ & $240 \mathrm{bp}$ & [12] \\
\hline & $\mathrm{R}$ & $5^{\prime}-$ AGGCCACAAGGGAACGCCTA -3' & & & \\
\hline \multirow[t]{2}{*}{ rpsl } & $\mathrm{F}$ & 5'- GGCCGACAAACAGAACGT -3' & $58^{\circ} \mathrm{C}(30 \mathrm{sec})$ & $375 \mathrm{bp}$ & [12] \\
\hline & $\mathrm{R}$ & 5'- GTTCACCAACTGGGTGAC -3' & & & \\
\hline \multirow[t]{2}{*}{ embc } & $\mathrm{F}$ & 5'- GTTCGACAAGCGCGCCACAC - -3' & $65^{\circ} \mathrm{C}(45 \mathrm{sec})$ & $334 \mathrm{bp}$ & [22] \\
\hline & $\mathrm{R}$ & 5'- CGGAGGTAGATGGTAGCCGG -3' & & & \\
\hline \multirow[t]{2}{*}{ embA } & $\mathrm{F}$ & 5'- GCCGGCTATGTAGCCAACTA -3' & $65^{\circ} \mathrm{C}(45 \mathrm{sec})$ & $338 \mathrm{bp}$ & [17] \\
\hline & $\mathrm{R}$ & 5'- GACCGTTCCACCAACACC -3' & & & \\
\hline \multirow[t]{2}{*}{$e m b B$} & $\mathrm{~F}$ & 5'- CCGACCACGCTGAAACTG -3' & $65^{\circ} \mathrm{C}(45 \mathrm{sec})$ & $368 \mathrm{bp}$ & [23] \\
\hline & $\mathrm{R}$ & 5'- GTAATACCAGCCGAAGGGATCCT -3' & & & \\
\hline \multirow[t]{2}{*}{$\operatorname{gid} B$} & $\mathrm{~F}$ & 5'-CGCCGAGTCGTTGTGCT-3' & $62^{\circ} \mathrm{C}(1 \mathrm{~min})$ & $886 \mathrm{pb}$ & - \\
\hline & $\mathrm{R}$ & 5'-AGCCTGGCCCGACCTTA-3' & & & \\
\hline
\end{tabular}

$\mathrm{T}^{\circ}=$ Temperature. 
obtaining a $10 \mu \mathrm{l}$ final volume. Unincorporated terminators were removed by treatment on a sephadex column. The obtained sequences were aligned using the assembling application of vector NTI (Invitrogen) and CodonCode Aligner, and polymorphisms detection was achieved by comparison with the published M. tuberculosis H37Rv sequence.

\section{Quality control}

M. tuberculosis H37Rv (ATCC 27294) was included as a quality controls for the phenotypic and genotypic tests.

\section{Results}

\section{Analysis of INH -resistance associated mutation}

A total of $44 \operatorname{INH}^{\mathrm{R}}(24$ high level and 20 low level) $)$ and 100 matched $\mathrm{INH}^{\mathrm{S}}$ sensitive control strains were screened for mutations at katG codon 315, the fabG1-inhA regulatory region, the inhA ORF, the $o x y R$-ahpC intergenic region by DNA sequence analysis. A complete list of specific mutations, which had been identified is provided in Table 2.

\section{Polymorphisms in the katG gene}

Among the 24 high level INH-resistant isolates, 18 (75\%) were genetically altered in the kat $G$ region. Out of these, $17(70.8 \%)$ had a resistance associated mutation in katG codon 315 and one isolate had a partial $k a t G$ gene deletion (Table 2).

Of the 18 isolates altered in the $k a t G$ gene, 7 had an additional mutation in the fabG1-inhA regulatory region ( 2 at position $-15 \mathrm{C} \rightarrow \mathrm{T}$ and 5 at position $-47 \mathrm{G} \rightarrow \mathrm{C}$ ). The katG315 mutations resulted in a change of the wildtype codon, AGC (Ser) to ACC (Thr) in 17 strains and AAC (Asn) in one strain. All of the INH susceptible strains lacked mutations in katG 315. Thus for detection of high level INH -resistance, mutation/partial deletion of the katG gene had a specificity of $100.0 \%$ and a sensitivity of $75 \%(18 / 44)$.

Of the 20 low level INH-resistant isolates, $2(10 \%)$ harboured the katG315 mutation. In total, the katG315 mutation was seen in 19 isolates with $16(84.2 \%)$ being high level INH-resistant isolates. Therefore, this mutation might be associated with high level INH -resistance $(1 \mu \mathrm{g} / \mathrm{ml})$. Overall, for the detection of INH -resistance, mutation/partial deletion of the katG gene had a specificity of $100.0 \%$ and a sensitivity of $45.5 \%(20 / 44)$.

\section{Polymorphisms in the inhA gene}

The inhA region consists of two genes, fabG1 and inhA. Among the 24 high level INH-resistant isolates, 3 harboured the mutation $-15 \mathrm{C} \rightarrow \mathrm{T}$ in the regulatory region of inhA with 2 of them carrying an additional katG315 mutation and 5 had nucleotide changes $(\mathrm{G} \rightarrow \mathrm{C})$ at position -47 . All the $5 \mathrm{INH}$-resistant isolates with $-47 \mathrm{G} \rightarrow \mathrm{C}$ mutation also harbored the katG315 mutation.

Out of the 20 low level INH-resistant isolates, 10 (50\%) had mutations in fabG1-inhA leading to a $\mathrm{C} \rightarrow$ T change at position -15 of the start site of fabG. In total, the fabG1inhA mutation at -15 position was observed in 13 isolates with 10 (77\%) being low level INH-resistant isolates. Therefore, this mutation seems to be associated with low level INH -resistance $(0.2 \mu \mathrm{g} / \mathrm{ml})$. None of the INH susceptible isolates had the mutation affecting the inhA promoter region at position -15 . On the contrary, the nucleotide change at position -47 was also seen in 24 isoniazid susceptible isolates and a new mutation $-102 \mathrm{C} \rightarrow \mathrm{T}$ not yet described was detected in 3 other INH susceptible isolates. No mutation was observed in inhA ORF gene (Table 3).

\section{Polymorphisms in the oxyR-ahpC intergenic region}

One low level INH-resistant isolate displayed a $\mathrm{G} \rightarrow \mathrm{A}$ substitution at position 32 upstream of the transcriptional

Table 2 Isoniazid resistance- associated mutations detected in $M$. tuberculosis study isolates

\begin{tabular}{|c|c|c|c|c|c|c|}
\hline \multirow[t]{2}{*}{ Gene } & \multirow[t]{2}{*}{$\begin{array}{l}\mathrm{N}^{\circ} \text { of isolates } \\
\text { tested }\end{array}$} & \multirow[t]{2}{*}{$\begin{array}{l}\mathrm{N}^{\circ} \text { of isolates with } \\
\text { indicated genotype }\end{array}$} & \multirow[t]{2}{*}{$\begin{array}{l}\text { Nucleotide } \\
\text { change }\end{array}$} & \multirow[t]{2}{*}{$\begin{array}{l}\text { Amino acid } \\
\text { change }\end{array}$} & \multicolumn{2}{|c|}{$\begin{array}{c}\mathrm{N}^{\circ} \text { of mutated isolates according } \\
\text { to INH resistance level }\end{array}$} \\
\hline & & & & & Low level $(0.2 \mu \mathrm{g} / \mathrm{ml})$ & High level $(1 \mu \mathrm{g} / \mathrm{ml})$ \\
\hline \multirow[t]{5}{*}{ katG } & $44 \mathrm{INH}^{\mathrm{R}}$ & 18 & $315 \mathrm{AGC} \rightarrow \mathrm{ACC}$ & $\mathrm{Ser} \rightarrow \mathrm{Thr}$ & 2 & 16 \\
\hline & & 1 & $315 \mathrm{AGC} \rightarrow \mathrm{AAC}$ & $\mathrm{Ser} \rightarrow$ Asn & 0 & 1 \\
\hline & & 1 & Partial deletion & NA & 0 & 1 \\
\hline & & 24 & WT & NA & 0 & 0 \\
\hline & $100 \mathrm{INH}^{\mathrm{S}}$ & 0 & WT & NA & NA & NA \\
\hline \multirow[t]{5}{*}{ fabG1-inhA regulatory region } & $44 \mathrm{INH}^{\mathrm{R}}$ & 13 & $-15 C \rightarrow T$ & NA & 10 & 3 \\
\hline & & 5 & $-47 G \rightarrow C$ & NA & 0 & 5 \\
\hline & & 26 & WT & NA & 0 & 0 \\
\hline & $100 \mathrm{INH}^{\mathrm{S}}$ & 24 & $-47 G \rightarrow C$ & NA & NA & NA \\
\hline & & 3 & $-102 C \rightarrow T$ & NA & NA & NA \\
\hline
\end{tabular}


Table 3 Rifampicin resistance-associated mutations detected in $\boldsymbol{M}$. tuberculosis study isolates

\begin{tabular}{ccccc}
\hline $\begin{array}{c}\text { Gene } \\
\text { of isolates } \\
\text { tested }\end{array}$ & $\begin{array}{c}\mathbf{N}^{\circ} \text { and type of isolates } \\
\text { with indicated } \\
\text { genotype }\end{array}$ & $\begin{array}{c}\text { Nucleotide } \\
\text { change }\end{array}$ & $\begin{array}{c}\text { Amino acid } \\
\text { change }\end{array}$ \\
\hline$r p o B$ & $7 \mathrm{RIF}^{\mathrm{R}}$ & 5 & $531 \mathrm{TCG} \rightarrow \mathrm{TTG}$ & $\mathrm{Ser} \rightarrow$ Leu \\
& & 1 & $526 \mathrm{CAC} \rightarrow \mathrm{GAC}$ & $\mathrm{His} \rightarrow \mathrm{Asp}$ \\
& 1 & $516 \mathrm{GAC} \rightarrow \mathrm{GTC}$ & $\mathrm{Asp} \rightarrow \mathrm{Val}$ \\
& $100 \mathrm{RIF}^{\mathrm{S}}$ & 1 & $516 \mathrm{GAC} \rightarrow \mathrm{TAC}$ & $\mathrm{Asp} \rightarrow \mathrm{Tyr}$ \\
\hline
\end{tabular}

$\mathrm{NA}=$ not applicable; $\mathrm{WT}=$ wild type; $\mathrm{RIF}^{\mathrm{R}}=$ rifampicin resistant isolate; $\mathrm{RIF}^{\mathrm{S}}=$ rifampicin sensitive isolate, $\mathrm{N}^{\circ}=$ Number .

start site of $a h p C$ in the $\operatorname{axy} R-a h p C$ intergenic region, which has previously been shown to be involved in INH -resistance [15].

\section{Combined sensitivity and specificity of katG and inhA promoter region for INH resistance}

Mutations in katG315 and $-15 \mathrm{C} \rightarrow \mathrm{T}$ in inhA promoter region accounted together for 73\% (33/44) INH -resistance. Since none of these mutations was observed in susceptible isolates, the combined specificity is $100 \%$.

Analysis of the $r p o B$ gene responsible for RIF-resistance In this study, 7 RIF $^{\mathrm{R}}$ isolates, and 100 RIF-sensitive $\left(\right.$ RIF $\left.^{\mathrm{S}}\right)$ clinical isolates were examined for mutations in a 158-bp fragment of $r p o B$ gene. Of $7 \mathrm{RIF}^{\mathrm{R}}$ isolates, resistanceassociated mutations in the core region of $r p o B$ were found in all 7 (100.0\%) isolates (Table 3$)$. The nucleotide and amino acid changes identified in drug-resistant isolates are shown in Table 4. Three different rpoB mutations were identified involving codons 516, 526, and 531. The most common mutation, which changes TCG (Ser) to TTG (Leu) in codon 531, was detected in 5 (71.4\%) of the 7 mutated RIF-resistant isolates (Table 3). A mutation affecting codon 516 and leading to a substitution of aspartate to tyrosine was observed in the rpoB gene of one RIF sensitive isolate. Hence, mutations in the $r p o B$ gene exhibited a sensitivity of $100.0 \%$ and a specificity of $99.0 \%$.

\section{Analysis of mutations in the target regions of \\ SM -resistance}

All strains were first sequenced $\left(27 \mathrm{SM}^{\mathrm{R}}\right.$ isolates and 100 fully susceptible isolates) in the $r r s$ gene. As none of the resistant strains displayed a mutation in this gene, sequence analysis of rpsL was performed. Among the 27 $\mathrm{SM}^{\mathrm{R}}$ strains 2 carried a mutation in rpsL gene at codon 43 and none showed a polymorphism at codon 88 . The 2 resistant isolates mutated at codon 43 had a Lys $\rightarrow$ Arg substitution (Table 4). The remainder of the phenotypically resistant strains $(\mathrm{n}=25)$ did not carry a mutation in rpsL gene and no changes were found in the drug-susceptible isolates. The specificity of rpsL43 mutation for resistance detection of $\mathrm{SM}^{\mathrm{R}}$ was $100 \%$.

Additionally all strains were sequenced in gidB gene. In this very polymorphic gene, 5 different mutations with 3 of them never been reported were found in $5 \mathrm{SM}^{\mathrm{R}}$ strains and 2 different mutations in $6 \mathrm{SM}^{\mathrm{S}}$ strains (see Table 4). The 5 mutations at codon $36 \mathrm{GTG} \rightarrow$ GGG, $48 \mathrm{CAT} \rightarrow$

Table 4 Streptomycin and ethambutol resistance-associated mutations detected in $M$. tuberculosis study isolates

\begin{tabular}{|c|c|c|c|c|c|}
\hline Resistance to & Gene & $\mathrm{N}^{\circ}$ and type of isolates tested & $\mathrm{N}^{\circ}$ of isolates with indicated genotype & Nucleotide change & Amino acid change \\
\hline \multirow[t]{9}{*}{ Streptomycin } & rpsL & $27 \mathrm{SM}^{\mathrm{R}}$ & 2 & $43 A A G \rightarrow A G G$ & Lys $\rightarrow$ Arg \\
\hline & & $100 \mathrm{SM}^{\mathrm{S}}$ & 0 & WT & NA \\
\hline & $\operatorname{gid} B$ & $27 \mathrm{SM}^{\mathrm{R}}$ & 1 & $138 \mathrm{GCG} \rightarrow \mathrm{CCG}$ & Ala $\rightarrow$ Pro \\
\hline & & & 1 & 79TTG $\rightarrow$ TGG & Leu $\rightarrow$ Trp \\
\hline & & & 1 & $75 \mathrm{CCG} \rightarrow \mathrm{TCG}$ & Pro $\rightarrow$ Ser \\
\hline & & & 1 & $48 \mathrm{CAT} \rightarrow$ AAT & $\mathrm{His} \rightarrow$ Asn \\
\hline & & & 1 & $36 \mathrm{GTG} \rightarrow \mathrm{GGG}$ & Val $\rightarrow$ Gly \\
\hline & & $100 S M^{S}$ & 3 & $205 \mathrm{GCA} \rightarrow \mathrm{GCG}$ & $\mathrm{Ala} \rightarrow \mathrm{Ala}^{*}$ \\
\hline & & & 3 & $16 \mathrm{CTT} \rightarrow \mathrm{CGT}$ & Leu $\rightarrow$ Arg \\
\hline \multirow[t]{7}{*}{ Ethambutol } & $e m b c$ & $2 \mathrm{EMB}^{\mathrm{R}}$ & 0 & WT & NA \\
\hline & & $100 \mathrm{EMB}^{\mathrm{S}}$ & 3 & $-20 \mathrm{~A} \rightarrow \mathrm{C}$ & NA \\
\hline & & & 3 & $-230 \mathrm{~A} \rightarrow \mathrm{C}$ & NA \\
\hline & $e m b A$ & $2 \mathrm{EMB}^{\mathrm{R}}$ & 0 & WT & NA \\
\hline & & $100 \mathrm{EMB}^{\mathrm{S}}$ & 3 & $330 \mathrm{CTG} \rightarrow \mathrm{TTG}$ & Leu $\rightarrow$ Leu* $^{*}$ \\
\hline & $e m b B$ & $2 \mathrm{EMB}^{\mathrm{R}} 100 \mathrm{EMB}^{\mathrm{S}}$ & 1 & 306 & Met $\rightarrow$ Val \\
\hline & & & 0 & WT & NA \\
\hline
\end{tabular}

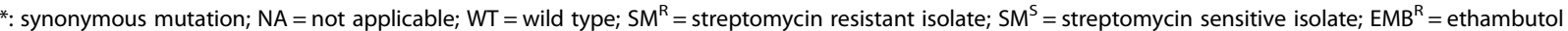
resistant isolate; $\mathrm{EMB}^{\mathrm{S}}=$ ethambutol sensitive isolate; $\mathrm{N}^{\circ}=$ Number. 
AAT, 75CCG $\rightarrow$ TCG, 79TTG $\rightarrow$ TGG, 138GCG $\rightarrow$ CCG were exclusively found in streptomycin resistant strains while the mutations at codon 205GCA $\rightarrow$ GCG and $16 \mathrm{CTT} \rightarrow$ CGT were exclusively found in streptomycin sensitive strains.

\section{Analysis of mutations in the target regions of EMB -resistance}

In this study, we analyzed polymorphisms in the $e m b C A B$ operon for 2 ethambutol resistant isolates and 100 ethambutol sensitive isolates. Among our 2 EMB -resistant isolates, sequence analysis of the $e m b B$ gene identified 1 isolate with EMB-resistance-associated nucleotide substitutions in codon 306ATG $\rightarrow$ GTG that result in amino acid replacement $(306 \mathrm{Met} \rightarrow \mathrm{Val})$ and the remaining isolate as well as all sensitive isolates had no amino acid replacements in $e m b B$ gene. As $e m b B$ mutations are not the only ones involved in EMB-resistance mechanisms in $M$. tuberculosis, we also analyzed $e m b C$ and $e m b A$ loci for mutations. Sequence analyses of $e m b C$ and $e m b A$ revealed no mutations in EMB -resistant isolates while 6 of 100 fully susceptible isolates have mutations at position $-20 \mathrm{~A} \rightarrow \mathrm{C}$ and $-230 \mathrm{~A} \rightarrow \mathrm{C}$ of $e m b C$ upstream region. Although the substitutions at position $-20 \mathrm{~A} \rightarrow \mathrm{C}$ were present only in EMB-susceptible organisms in our sample, these three strains also had synonymous mutation at codon 330CTG $\rightarrow$ TTG of the $e m b A$ gene and nucleotides replacement at position $-102 \mathrm{C} \rightarrow \mathrm{T}$ in the regulatory region of fabG1-inhA operon; this is exclusively found in susceptible organisms. The 3 samples with mutations at position $-230 \mathrm{~A} \rightarrow \mathrm{C}$ also harbored simultaneously a nucleotide replacement at position -47 in the regulatory region of fabG1-inhA operon. Three of 100 fully susceptible strains had synonymous mutations at codon 330CTG $\rightarrow$ TTG of $e m b A$ gene, which did not resulting in amino acid replacement. These 3 isolates harbored simultaneously nucleotide replacement at position -20 upstream of the initiation site of $e m b C$ gene. All EMB susceptible strains $(n=100)$ had a wild-type $e m b B$ sequence.

\section{Discussion}

Early detection of drug resistance constitutes one of the priorities of TB control programs. It allows initiation of the appropriate treatment in patients and avoids dissemination of resistant strains in the community. In the context of a poor resource country, detection of drug resistance is performed in the reference laboratory by so-called 'conventional methods' based on detection of growth of $M$. tuberculosis in the presence of the respective antibiotics. Depending on the method, this process requires at least 10 days to 8 weeks before drug sensitivity results are available. During this time the infected patient may be treated incorrectly which may have serious health implications in particular in patients with HIV-TB coinfection. The disclosure of the genetic basis of resistance to anti-tuberculous agents has enabled development of new molecular tests to detect mutations associated with reduced susceptibility to antituberculous drugs $[9,10]$. In order to detect and validate the drug resistance associated mutations, DNA sequencing is the most accurate among the molecular techniques. We used PCR fragment sequencing since molecular mechanisms explaining resistance to anti-tuberculous agents are not fully understood [24]. It presents the advantage, over methods that use DNA probes, to detect unknown mutations. Recently the GeneXpert has been endorsed by the WHO for point of care testing [25]. Drug sensitivity testing with this method is based on the detection of mutations in the core region of the $r p o B$ gene, thus only RIF-resistance or MDR would be detected.

In this study, we set out to investigate the association of phenotypic resistance with genetic mutations in drug resistance TB isolates in Cameroon. The majority of the isolates in this study were from the Jamot Hospital (Central Region of Cameroon), the reference hospital for diagnostic and treatment of pulmonary diseases throughout the country. Therefore, the data obtained in this study can be considered to be representative of the make-up of resistance conferring mutations present in M. tuberculosis strains in this region.

A 158-bp fragment of the rpoB gene from codon 507 to 533 was amplified and sequenced to detect mutations in $\mathrm{RIF}^{\mathrm{R}}$ strains. Of the 7 phentotypically $\mathrm{RIF}^{\mathrm{R}}$ strains, mutations were found in the rifampicin resistant determining region (RRDR) for all the 7 isolates. These alterations affected the codons Ser531Thr (71.4\%), His526Asp (14.3\%) and Asp516Val (14.3\%). The rpoB codons 531, 526, and 516 are the most frequently mutated codons worldwide, although variations in the relative frequencies of mutations in these codons have been described for M. tuberculosis isolates from different geographic locations. The most common site of nucleotide substitutions in $\operatorname{RIF}^{\mathrm{R}}$ isolates was codon 531. This finding was similar to those reported in Russia [26], the US [27], Tunisia [28] Ghana [21] and Germany [29]. The codon 531 mutation was also reported as the most frequent (68\%) in M. tuberculosis isolates of the LAM family in Cameroon [30]. For codons 526 and 516 involved in RIF $^{\mathrm{R}}$, mutations in our strains occurred at equal frequencies than in strains from other geographical regions [31-33]. It has been shown that various substitutions in the same codon can lead to different level of resistance. Mutations at codon 516 of the rpoB gene can confer either low or high level resistance depending on the codon change [34]. It has been reported that substitution of aspartate by tyrosine in codon 516 induced RIF-resistance of M. tuberculosis with minimum inhibitory concentration (MIC) between 
$15 \mu \mathrm{g} / \mathrm{ml}$ and $25 \mu \mathrm{g} / \mathrm{ml}$ in BACTEC 460-TB system [34]. In our study, RIF susceptibility was evaluated in Lowenstein Jensen at a concentration of $50 \mu \mathrm{g} / \mathrm{ml}$. This might explain why strains harbouring this mutation in our study were phenotypically RIF-susceptible. Among the 7 isolates which were altered genetically, 6 were MDR strains and one a RIF-SM-resistant isolate. Thus, $r p o B$ could be an indicator of multidrug resistance among $M$. tuberculosis strains. This observation was previously reported among Cameroonian M. tuberculosis isolates [30].

It has been previously shown that about $10-15.9 \%$ of RIF - resistant isolates do not have mutations in the RRDR [15]. More than 90\% of RIF -resistant strains from other regions had mutations located in the 81-bp core region [35-38]. This indicated a possible occurrence of alteration outside the core region of $81 \mathrm{bp}$ of the examined rpoB. Among other explanations, several additional genes might be involved in RIF-resistance such as $r p o A, r p o C$ or rpoD [39]. The natural resistance to RIF in some $M$. avium and M. intracellular strains is known to be a result of efficient cell wall permeability and exclusion barrier, suggesting that these elements could also play an important role in $M$. tuberculosis [34]. However, in our study, all the isolates harboured mutations in the RRDR core region.

Common genes known to be involved in INH-resistance are katG, inhA, ahpC, oxyR [10]. Several investigators have shown that INH-resistance in $M$. tuberculosis isolates arise principally from a katG gene alteration [40-42] that corresponds essentially to point mutations in codon 315 (point mutations in two bases 944 and 945). In this study, 18 (40.0\%) INH -resistant isolates were genetically altered in the $k a t G$ codon 315 . Others studies have reported $95 \%$ of all INH-resistant isolates with mutations in codon 315 [43]. Out of the $6 \mathrm{MDR}$ strains identified in this study, 5 displayed a high level resistance to isoniazid with a katG alteration and the remaining one displayed a low level INH-resistance with $-32 \mathrm{G} \rightarrow \mathrm{A}$ mutation in oxyR-ahpC intergenic region. Therefore, it will be useful to combine katG315 and -15 point mutation inhA promoter region with $r р о B$ in molecular assays looking at drug resistance. Since some of the $\mathrm{INH}^{\mathrm{R}}$ strains in this study had no mutation in katG315 and $-15 \mathrm{inh} A$ promoter region, it is likely that mutations in other genes, such as the inhA locus, contribute to resistance. Previous studies have shown that mutations in the upstream region of the inhA locus result in increased levels of $\operatorname{Inh} A$ (NADH-dependent enoyl-acyl carrier protein reductase) expression, thereby elevating the drug target levels and producing INH -resistance via a titration mechanism [15]. We assessed for mutations in the inhA regulatory region of all the $44 \mathrm{INH}^{\mathrm{R}} M$. tuberculosis strains and found a substitution at position 15 upstream of the start codon in $13(28.9 \%)$ isolates. The frequency of the occurrence of specific INH-resistance conferring mutations varied between geographical regions in the world [26]. A study in Equatorial Guinea reported the absence of mutation in the katG gene of $M$. tuberculosis INH -resistant isolates [44]. The unique katG mutation observed in this study was the substitution of Serine to Threonine at codon 315. High proportion of Ser315katG mutations has been reported in Russia (76.9\%) [26], in Morocco (68.6\%) [45], in isolates of the LAM family in Cameroon [30] and also in Korea (49.1\%) [46]. In $\mathrm{INH}^{\mathrm{R}}$ strains, neither insertions nor complete deletions of $k a t G$ were found, which is evidence of the rare occurrence of these mutations in clinical isolates, although they were reported previously by other authors $[47,48]$. Fourteen $(31.8 \%) \mathrm{INH}^{\mathrm{R}}$ isolates did not show mutations at the four loci analyzed. This discrepancy between the phenotypic results and the genotypic drug resistance tests could be attributed to the presence of other mutations located either outside the selected target region or the selected genes. Several others studies have reported that mutations in inhA or its promoter region are usually associated with low-level resistance of INH. Moreover, INH-resistant isolates with inhA mutations can have additional mutations in $k a t G$, conferring higher levels of INH-resistance [11].

All mutations found in fabG1-inhA promoter region were not associated with phenotypic resistance. The substitution of $\mathrm{G}$ to $\mathrm{C}$ at position -47 first described by Homolka and al. [21] in an INH-resistant strain has been found in both susceptible $(24 / 44 ; 54.5 \%)$ and resistant isolates $(5 / 44 ; 11.4 \%)$. Thus, this mutation seems to not correlate with INH-resistance. The mutation $-102 \mathrm{C} \rightarrow \mathrm{T}$ not yet described is also not relevant to INH-resistance since it was found only in susceptible isolates.

The analysis of SM-resistance mechanism revealed that none of the SM-resistant strains carried a mutation in the rrs gene although those mutations have been described as main resistance mechanism that confer high level SM -resistance [12]. Clinical isolates showing no mutations in rpsL or rrs gene have been reported in the literature [49]. A previous investigation from Cameroon encountered rpsL or rrs mutations in SM-resistant isolates from the Central Region of Cameroon [50]. In contrast in the current investigation only rpsL mutations were associated with SM-resistance. This indicates that further studies are necessary to delineate the molecular markers for SM-resistance. Mutations in the rpsL locus have been hypothesized to be an alternative mechanism of SM-resistance like mutations in the $\operatorname{gidB}$ [51] or efflux pumps [13]. Overall, we detected gidB mutations in $18.5 \%$ of SM-resistant isolates and $6 \%$ of SM susceptible isolates. Although the encountered mutations in resistant samples were not observed in susceptible isolates, their association with SM-resistance needs to be confirmed. 
Three contiguous genes encoding arabinosyl transferases and designated $e m b C, e m b A$, and $e m b B$ were analyzed in the present study. These 3 genes have been identified in $M$. tuberculosis [52]. Previous studies based on limited sequencing region containing the $e m b C A B$ genes have identified mutations that result in replacement of amino acid residues and are found only in EMB-resistant organisms cultured from humans [52]. In this study, the $e m b B$ analysis gene identified 1 of 2 resistant isolates with EMBresistance-associated nucleotide substitutions in codon 306ATG $\rightarrow$ GTG that result in amino acid replacement (Met $\rightarrow \mathrm{Val}$ ). This is in accordance with others studies analyzing EMB-resistant clinical isolates of $M$. tuberculosis that identified $e m b B$ amino acid-conferring mutations in approximately 50 to $70 \%$ isolates with resistanceassociated polymorphisms [52]. Certain variations affecting embA (330CTG $\rightarrow$ TTG) and $e m b C(-20 \mathrm{~A} \rightarrow \mathrm{C}$ and $-230 \mathrm{~A} \rightarrow \mathrm{C}$ ) appeared to be not associated with drug resistance. Given the low number of EMB-resistant isolates in our investigation further studies are needed to confirm these findings.

\section{Conclusion}

This study provided the first molecular characterization of $M$. tuberculosis drug resistance in the Central Region of Cameroon using DNA sequencing. rpoB and katG315 mutations known to be involved in resistance had high specificities and sensitivities for detecting RIF- and INHresistance respectively. However, the correlation between molecular and phenotypic resistance testing for the determination of SM- and EMB-resistance was lower. This study clearly shows the need for continuous phenotypic and genotypic characterization of drug resistance at the national level in order to determine the most suitable molecular marker for drug resistance in our setting. The fact that mutations at codon katG315 and at the rpoB gene show high specificities for resistance against INH or RIF respectively suggests that these may be suitable molecular marker for diagnostic test in Cameroon. Consequently the WHO recommended GeneXpert technology is appropriate for the detection RIF-resistance in the Central Region of Cameroon.

\footnotetext{
Abbreviations

TB: Tuberculosis; MDR: Multi-drug resistance; SLD: Second-line drug; DOTS: Directly observed treatment short course; HIV: Human immunodeficiency virus; ATCC: American type culture collection; INH: Isoniazid; RIF: Rifampicin; SM: Streptomycin; EMB: Ethambutol; AST: Antimicrobial susceptibility testing; MIC: Minimal inhibitory concentration; DNA: Désoxyribonucleic acid; CANTAM: Central Africa Network on Tuberculosis, AIDS/HIV and Malaria; RRDR: Rifampicin resistant determining region.
}

\section{Competing interests}

The authors declare there are no competing interests.

\section{Authors' contributions}

EMT and LKS contributed equally, they carried out all the molecular analysis as Ph.D students, participated in field work and drafted the manuscript. JPAA, JCT, ST, GGM, ALTW participated in field work and revised the manuscript. CK participated in the conception, design and supervision of field work. SE supervised mycobacteria culture and DST. FN is the coordinator and project manager of the CANTAM network. She revised the manuscript. VNPB is the Workpackage Leader of the CANTAM-TB project. She was the overall supervisor and chief designer of the project and critically revised the manuscript. MF is the Co-Workpackage Leader of CANTAM-TB project and Coordinator of the DAAD PAGEL-Program of the University of Tübingen. He designed and supervised the molecular analysis and critically revised the manuscript. All authors read and approved the final manuscript before submission.

\section{Acknowledgements}

This study was financially supported by CANTAM EDCTP grant $\mathrm{N}^{\circ}$ CB.2007.41700.006. Emmanuel Mouafo Tekwu and Larissa Kamgue Sidze were research fellow students at the Institute for Tropical Medicine in Tübingen (Germany). Veronique Penlap Beng, Francine Ntoumi, Emmanuel Mouafo Tekwu, Larissa Kamgue Sidze, Jean-Paul Assam Assam and Matthias Frank were supported by the DAAD PAGEL-Program of the University of Tübingen to attend expert meetings and workhops throughout the duration of the project. We thank Mrs Augusta Tsasse, the technician at the Centre Pasteur of Yaoundé; Dr Ellen Bruske and Mrs Andrea Weierich of the University of Tübingen (Germany) for their technical assistance.

\section{Author details}

${ }^{1}$ Laboratory for Tuberculosis Research (LTR), Biotechnology Centre (BTC)-Nkolbison, University of Yaoundé I, Yaoundé, Cameroon. ${ }^{2}$ Pneumology unit, Jamot Hospital, Yaoundé, Cameroon. ${ }^{3}$ Mycobacteriology Service, Reference laboratory of NTP, Centre Pasteur of Cameroon-Pasteur Institute International Network, Yaoundé, Cameroon. ${ }^{4}$ Fondation Congolaise pour la Recherche Médicale, Université Marien Gouabi, Brazzaville, Congo. ${ }^{5}$ Institute for Tropical Medicine, University of Tübingen, Tübingen, Germany. ${ }^{6} \mathrm{Central}$ African Network for Tuberculosis, AIDS/HIV and Malaria (CANTAM), Brazzaville, Congo. ${ }^{7}$ Deutsches Zentrum für Infektionsforschung (DZIF), Tübingen, Germany.

Received: 13 January 2014 Accepted: 29 April 2014 Published: 3 May 2014

\section{References}

1. Cauthen GM, Dooley SW, Onorato IM, Ihle WW, Burr JM, Bigler WJ, Witte J, Castro KG: Transmission of Mycobacterium tuberculosis from tuberculosis patients with HIV infection or AIDS. Am J Epidemiol 1996, 144(1):69-77.

2. Gandhi NR, Moll A, Sturm AW, Pawinski R, Govender T, Lalloo U, Zeller K, Andrews J, Friedland G: Extensively drug-resistant tuberculosis as a cause of death in patients co-infected with tuberculosis and HIV in a rural area of South Africa. Lancet 2006, 368(9547):1575-1580.

3. WHO: Global Tuberculosis Control: WHO Report 2011. Geneva, Switzerland: WHO/HTM/TB/2011.16; 2011.

4. WHO: Global Tuberculosis Report 2012. Geneva Switzerland: WHO/HTM/TB/ 20126; 2012

5. Gillespie SH: Evolution of drug resistance in Mycobacterium tuberculosis: clinical and molecular perspective. Antimicrob Agents Chemother 2002, 46(2):267-274

6. Shah NS, Richardson J, Moodley P, Moodley S, Babaria P, Ramtahal M, Heysell SK, Li X, Moll AP, Friedland G, Sturm AW, Gandhi NR: Increasing drug resistance in extensively drug-resistant tuberculosis South Africa. Emerg Infect Dis 2011, 17(3):510-513.

7. Cole ST, Brosch R, Parkhill J, Garnier T, Churcher C, Harris D, Gordon SV, Eiglmeier K, Gas S, Barry CE 3rd, Tekaia F, Badcock K, Basham D, Brown D, Chillingworth T, Connor R, Davies R, Devlin K, Feltwell T, Gentles S, Hamlin N, Holroyd S, Hornsby T, Jagels K, Krogh A, McLean J, Moule S, Murphy L, Oliver K, Osborne J, Quail MA, Rajandream MA, Rogers J, Rutter S, Seeger K, Skelton J, Squares R, Squares S, Sulston JE, Taylor K, Whitehead S, Barrell BG: Deciphering the biology of Mycobacterium tuberculosis from the complete genome sequence. Nature 1998, 393(6685):537-544. 
8. Shamputa IC, Rigouts L, Portaels F: Molecular genetic methods for diagnosis and antibiotic resistance detection of mycobacteria from clinical specimens. APMIS 2004, 112(11-12):728-752.

9. Boehme CC, Nabeta P, Hillemann D, Nicol MP, Shenai S, Krapp F, Allen J, Tahirli R, Blakemore R, Rustomjee R, Milovic A, Jones M, O'Brien SM, Persing DH, Ruesch-Gerdes S, Gotuzzo E, Rodrigues C, Alland D, Perkins MD: Rapid molecular detection of tuberculosis and rifampin resistance. $N$ Engl J Med 2010, 363(11):1005-1015

10. Garcia De Viedma D: Rapid detection of resistance in Mycobacterium tuberculosis: a review discussing molecular approaches. Clin Microbiol Infect 2003, 9(5):349-359.

11. Zhang Y, Yew WW: Mechanisms of drug resistance in Mycobacterium tuberculosis. Int J Tuberc Lung Dis 2009, 13(11):1320-1330.

12. Sreevatsan S, Pan X, Stockbauer KE, Williams DL, Kreiswirth BN, Musser JM: Characterization of $r p s L$ and rrs mutations in streptomycin-resistant Mycobacterium tuberculosis isolates from diverse geographic localities. Antimicrob Agents Chemother 1996, 40(4):1024-1026.

13. Okamoto S, Tamaru A, Nakajima C, Nishimura K, Tanaka Y, Tokuyama S, Suzuki Y, Ochi K: Loss of a conserved 7-methylguanosine modification in 16S rRNA confers low-level streptomycin resistance in bacteria. Mol Microbiol 2007, 63(4):1096-1106.

14. Plinke $C$, Rüsch-Gerdes $S$, Niemann S: Significance of mutations in embB codon 306 for prediction of ethambutol resistance in clinical Mycobacterium tuberculosis isolates. Antimicrob Agents Chemother 2006, 50(5):1900-1902.

15. Ramaswamy S, Musser JM: Molecular genetic basis of antimicrobial agent resistance in Mycobacterium tuberculosis: 1998 update. Tuber Lung Dis 1998, 79(1):3-29.

16. Plinke C, Cox H, Zarkua N, Karimovich H, Braker K, Diel R, Rüsch-Gerdes S, Feuerriegel $S$, Niemann S: embCAB sequence variation among ethambutol-resistant Mycobacterium tuberculosis isolates without embB306 mutation. J Antimicrob Chemother 2010, 65:1359-1367.

17. Jadaun GPS, Das R, Prashant U, Chauhan DS, Charma VD, Katoch VM: Role of embCAB gene mutations in ethambutol resistance in Mycobacterium tuberculosis isolates from India. Int J Antimicrob Agents 2009, 33:483-486.

18. Dalla Costa ER, Ribeiro MO, Silva MS, Arnold LS, Rostirolla DC, Cafrune PI, Espinoza RC, Palaci M, Telles MA, Ritacco V, Suffys PN, Lopes ML, Campelo $\mathrm{CL}$, Miranda SS, Kremer K, da Silva PE, Fonseca Lde S, Ho JL, Kritski AL, Rossetti ML: Correlations of mutations in katG, oxyR-ahpC and inhA genes and in vitro susceptibility in Mycobacterium tuberculosis clinical strains segregated by spoligotype families from tuberculosis prevalent countries in South America. BMC Microbiol 2009, 9:39.

19. Dolgin E: African networks launch to boost clinical trial capacity. Nat Med 2010, 16(1):8.

20. Canetti G, Fox W, Khomenko A, Mahler HT, Menon NK, Mitchison DA, Rist N, Smelev NA: Advances in techniques of testing mycobacterial drug sensitivity, and the use of sensitivity tests in tuberculosis control programmes. Bull World Health Organ 1969, 41(1):21-43.

21. Homolka S, Meyer CG, Hillemann D, Owusu-Dabo E, Adjei O, Horstmann RD, Browne EN, Chinbuah A, Osei I, Gyapong J, Kubica T, Ruesch-Gerdes S, Niemann S: Unequal distribution of resistance-conferring mutations among Mycobacterium tuberculosis and Mycobacterium africanum strains from Ghana. Int J Med Microbiol 2010, 300(7):489-495.

22. Sreevatsan S, Stockbauer KE, Pan X, Kreiswirth BN, Moghazeh SL, Jacobs WR $\mathrm{Jr}$, Telenti A, Musser JM: Ethambutol resistance in Mycobacterium tuberculosis: critical role of embB mutations. Antimicrob Agents Chemother 1997, 41(8):1677-1681

23. Srivastavaa S, Ayyagaria A, Dholea TN, Nyatia KK, Dwivedi SK: Emb nucleotide polymorphisms and the role of embB306 mutations in Mycobacterium tuberculosis resistance to ethambutol. Int J Med Microbiol 2009, 299:269-280.

24. Abbadi SH, Sameaa GA, Morlock G, Cooksey RC: Molecular identification of mutations associated with anti-tuberculosis drug resistance among strains of Mycobacterium tuberculosis. Int J Infect Dis 2009, 13(6):673-678.

25. Nakiyingi L, Nankabirwa H, Lamorde M: Tuberculosis diagnosis in resource-limited settings: clinical use of GeneXpert in the diagnosis of smear-negative PTB: a case report. Afr Health Sci 2013, 13(2):522-524.

26. Afanas'ev MV, Ikryannikova LN, I'ina EN, Sidorenko SV, Kuz'min AV, Larionova EE, Smirnova TG, Chernousova LN, Kamaev EY, Skorniakov SN, Kinsht VN, Cherednichenko AG, Govorun VM: Molecular characteristics of rifampicin- and isoniazid-resistant Mycobacterium tuberculosis isolates from the Russian Federation. J Antimicrob Chemother 2007 59(6):1057-1064

27. Campbell PJ, Morlock GP, Sikes RD, Dalton TL, Metchock B, Starks AM, Hooks DP, Cowan LS, Plikaytis BB, Posey JE: Molecular detection of mutations associated with first and second-line drug resistance compared with conventional drug susceptibility testing in M. tuberculosis. Antimicrob Agents Chemother 2011, 55(5):2032-2041.

28. Soudani A, Hadjfredj S, Zribi M, Masmoudi A, Messaoud T, Tiouri H, Fendri C: Characterization of Tunisian Mycobacterium tuberculosis rifampin-resistant clinical isolates. J Clin Microbiol 2007, 45(9):3095-3097.

29. Hillemann D, Weizenegger M, Kubica T, Richter E, Niemann S: Use of the genotype MTBDR assay for rapid detection of rifampin and isoniazid resistance in Mycobacterium tuberculosis complex isolates. J Clin Microbiol 2005, 43(8):3699-3703.

30. Penlap BV, Victor T, Warren R, Jordaan A, Tedom ES, Titanji V: Evidence of drug resistance among the LAM-Cameroon family in Mycobacterium tuberculosis isolates from Yaoundé Cameroon. Cam J Acad Sc 2010, 9(1):11-15

31. Taniguchi $H$, Aramaki $H$, Nikaido $Y$, Mizuguchi $Y$, Nakamura M, Koga T, Yoshida S: Rifampicin resistance and mutation of the rpoB gene in Mycobacterium tuberculosis. FEMS Microbiol Lett 1996, 144(1):103-108.

32. Pozzi G, Meloni M, Iona E, Orru G, Thoresen OF, Ricci ML, Oggioni MR, Fattorini L, Orefici G: rpoB mutations in multidrug-resistant strains of Mycobacterium tuberculosis isolated in Italy. J Clin Microbiol 1999, 37(4):1197-1199.

33. Qian L, Abe C, Lin TP, Yu MC, Cho SN, Wang S, Douglas JT: rpoB genotypes of Mycobacterium tuberculosis Beijing family isolates from East Asian countries. J Clin Microbiol 2002, 40(3):1091-1094.

34. Zaczek A, Brzostek A, Augustynowicz-Kopec E, Zwolska Z, Dziadek J: Genetic evaluation of relationship between mutations in $r p o B$ and resistance of Mycobacterium tuberculosis to rifampin. BMC Microbiol 2009, 9:10.

35. Telenti A, Imboden P, Marchesi F, Lowrie D, Cole S, Colston MJ, Matter L, Schopfer K, Bodmer T: Detection of rifampicin-resistance mutations in Mycobacterium tuberculosis. Lancet 1993, 341(8846):647-650.

36. Williams DL, Waguespack C, Eisenach K, Crawford JT, Portaels F, Salfinger M, Nolan CM, Abe C, Sticht-Groh V, Gillis TP: Characterization of rifampinresistance in pathogenic mycobacteria. Antimicrob Agents Chemother 1994, 38(10):2380-2386.

37. Ohno H, Koga H, Kohno S, Tashiro T, Hara K: Relationship between rifampin MICs for and rpoB mutations of Mycobacterium tuberculosis strains isolated in Japan. Antimicrob Agents Chemother 1996, 40(4):1053-1056

38. Mani C, Selvakumar N, Narayanan S, Narayanan PR: Mutations in the rpoB gene of multidrug-resistant Mycobacterium tuberculosis clinical isolates from India. J Clin Microbiol 2001, 39(8):2987-2990.

39. Johnson R, Streicher EM, Louw GE, Warren RM, van Helden PD, Victor TC: Drug Resistance in Mycobacterium tuberculosis. Curr Issues Mol Biol 2009, 8:97-112.

40. Mokrousov I, Narvskaya O, Otten T, Limeschenko E, Steklova L, Vyshnevskiy B: High prevalence of KatG Ser315Thr substitution among isoniazid-resistant Mycobacterium tuberculosis clinical isolates from northwestern Russia, 1996 to 2001. Antimicrob Agents Chemother 2002, 46(5):1417-1424.

41. Sajduda A, Brzostek A, Poplawska M, Augustynowicz-Kopec E, Zwolska Z Niemann S, Dziadek J, Hillemann D: Molecular characterization of rifampin- and isoniazid-resistant Mycobacterium tuberculosis strains isolated in Poland. J Clin Microbiol 2004, 42(6):2425-2431.

42. van Doorn HR, An DD, de Jong MD, Lan NT, Hoa DV, Quy HT, Chau NV, Duy PM, Tho DQ, Chinh NT, Farrar JJ, Caws M: Fluoroquinolone resistance detection in Mycobacterium tuberculosis with locked nucleic acid probe real-time PCR. Int J Tuberc Lung Dis 2008, 12(7):736-742.

43. Bakonyte D, Baranauskaite A, Cicenaite J, Sosnovskaja A, Stakenas P: Molecular characterization of isoniazid-resistant Mycobacterium tuberculosis clinical isolates in Lithuania. Antimicrob Agents Chemother 2003, 47(6):2009-2011.

44. Tudo G, Gonzalez J, Obama R, Rodriguez JM, Franco JR, Espasa M, Simarro PR, Escaramis G, Ascaso C, Garcia A, Jimenez De Anta MT: Study of resistance to anti-tuberculosis drugs in five districts of Equatorial Guinea: rates, risk factors, genotyping of gene mutations and molecular epidemiology. Int J Tuberc Lung Dis 2004, 8(1):15-22.

45. Chaoui I, Sabouni R, Kourout M, Jordaan AM, Lahlou O, Elouad R, Akrim M, Victor TC, El Mzibri M: Analysis of isoniazid, streptomycin and ethambutol 
resistance in Mycobacterium tuberculosis isolates from Morocco. $J$ Infect Dev Ctries 2009, 3(4):278-284.

46. Cho EH, Bae HK, Kang SK, Lee EH: Detection of isoniazid and rifampicin resistance by sequencing of $k a t G$, inhA, and $r p o B$ genes in Korea. Korean J Lab Med 2009, 29(5):455-460.

47. Siddiqi N, Shamim M, Hussain S, Choudhary RK, Ahmed N, Prachee BS, Savithri GR, Alam M, Pathak N, Amin A, Hanief M, Katoch VM, Sharma SK, Hasnain SE: Molecular characterization of multidrug-resistant isolates of Mycobacterium tuberculosis from patients in North India. Antimicrob Agents Chemother 2002, 46(2):443-450.

48. Torres MJ, Criado A, Gonzalez N, Palomares JC, Aznar J: Rifampin and isoniazid resistance associated mutations in Mycobacterium tuberculosis clinical isolates in Seville Spain. Int J Tuberc Lung Dis 2002, 6(2):160-163.

49. Tudo G, Rey E, Borrell S, Alcaide F, Codina G, Coll P, Martin-Casabona N, Montemayor M, Moure R, Orcau A, Salvado M, Vicente E, Gonzalez-Martin J: Characterization of mutations in streptomycin-resistant Mycobacterium tuberculosis clinical isolates in the area of Barcelona. J Antimicrob Chemother 2010, 65(11):2341-2346.

50. Mbacham FW, Tientcheu LD, Beng Penlap V, Kuaban C, Eyangoh S, Wang H, Bickii J, Netongo PM, Titi Lembe W, Olama A, Njikam N, Teyim P, Khan B: Detection of resistance-associated mutations in Mycobacterium tuberculosis isolates in Cameroon using a dot-blot hybridisation technique. Afr J Biotechnol 2011, 10(53):1 1016-11022.

51. Silva PE, Bigi F, Santangelo MP, Romano MI, Martin C, Cataldi A, Ainsa JA Characterization of P55, a multidrug efflux pump in Mycobacterium bovis and Mycobacterium tuberculosis. Antimicrob Agents Chemother 2001, 45 (3):800-804

52. Telenti A, Philipp WJ, Sreevatsan S, Bernasconi C, Stockbauer KE, Wieles B, Musser JM, Jacobs WR Jr: The emb operon, a gene cluster of Mycobacterium tuberculosis involved in resistance to ethambutol. Nat Med 1997, 3(5):567-570.

doi:10.1186/1471-2180-14-113

Cite this article as: Tekwu et al: Sequence analysis for detection of drug resistance in Mycobacterium tuberculosis complex isolates from the Central Region of Cameroon. BMC Microbiology 2014 14:113.

\section{Submit your next manuscript to BioMed Central and take full advantage of:}

- Convenient online submission

- Thorough peer review

- No space constraints or color figure charges

- Immediate publication on acceptance

- Inclusion in PubMed, CAS, Scopus and Google Scholar

- Research which is freely available for redistribution 